\title{
Divino Amore. Historia sanktuarium w zarysie i antropologiczny komentarz
}

\author{
Divino Amore. An Outline of the History \\ of Sanctuary and Anthropological Commentary
}

\section{Kościelne i pielgrzymie opowieści o sanktuarium}

W trakcie studiów doktoranckich w Rzymie, w latach 80. XX w., mieszkałem przy kościele Quo Vadis. Przez pięć lat obserwowałem, jeszcze bez zamiaru badawczego, pielgrzymów², którzy udawali się do sanktuarium Divino Amore, położonego kilkanaście kilometrów od starożytnej świątyni. Pielgrzymki te odbywają się w każdą sobotę, od pierwszej po Wielkanocy do ostatniej w październiku. Ich tradycja sięga pierwszej połowy wieku XVIII³. Pątnicy gromadzą się przy obelisku Axum znajdującym się w pobliżu głów-

* Succursale della Facoltà di Teologia della Pontificia Università Lateranese, Istituto Superioredi Scienze Religiose „Alberto Trocchi” (Civita Castellana, Italia)

I Część artykułu napisana przez ks. Władysława Zarębczana - przyp. red.

2 Pamiętam, że któregoś roku jeden z moich starszych współbraci krzątał sie już od rana, aby godnie przyjąć pielgrzymów, którzy przy kościele Quo Vadis kończyli pierwszy etap wędrówki. W oknie swego pokoju wystawiał przygotowany wcześniej i ozdobiony kwiatami i zniczami obraz Matki Bożej Częstochowskiej. Błogosławił pątników, rozmawiał z nimi. Oni dziękowali oklaskami i śpiewem pieśni Madonna nera (Czarna Madonna). Przeważnie odbywało się to około godziny pierwszej w nocy i chcąc nie chcąc, mieszkańcy okolicznych domów mieli wtedy obowiązkową pobudkę. Wiedząc o tym, kładłem się spać dopiero wtedy, kiedy grupa poszła dalej.

3 Od czasów pontyfikatu Jana Pawła II, w maju i w październiku, duszpasterze polskiego kościoła św. Stanisława w Rzymie organizują pielgrzymki Polaków do sanktuarium Divino Amore. Bywały lata, że grupy polskich pątników liczyły ponad tysiąc osób. 
nej siedziby FAO, niedaleko Cyrku Maksencjusza, i o północy wyruszają w drogę. Do pokonania mają około $15 \mathrm{~km}$.

Pielgrzymka do sanktuarium Divino Amore, tak jak inne pielgrzymki, ma charakter głęboko religijny. Jest nieprzerwanym „marszem śpiewu, modlitwy i pokuty" ${ }^{4}$. W tej wędrówce przez historię, śladami pierwszych chrześcijan, do korzeni duchowej tożsamości pomagają piękne i sugestywne widoki starożytnych arterii Appia Antica i Ardeatina. Tymi samymi drogami podążali kiedyś Apostołowie Piotr i Paweł oraz wielu męczenników. Kościół Quo Vadis, katakumby św. Kaliksta i św. Sebastiana strzegą pamięci pierwszych chrześcijan. Po drodze pielgrzymi mijają pomnik poległych, Fosse Ardeatines, modląc się w intencji ofiar wojen, przemocy i terroryzmu. Następnie zostawiają za plecami miasto z jego zgiełkiem i wędrują dalej pogrążeni w modlitwie aż do samego sanktuarium. Tradycja wymusza dotarcie na poranną mszę o godzinie piątej rano.

Divino Amore usytuowane jest na niewielkim wzgórzu, w odległości kilkunastu kilometrów od Rzymu, w pobliżu miejscowości Castel di Leva ${ }^{6}$. Współcześnie jest ono najważniejszym sanktuarium maryjnym całej Prowincji Rzymskiej.

Miejsce to jest wymienione po raz pierwszy w bulli papieża Grzegorza VII w I08I r. pod nazwą Castellione i jest zaznaczone jako własność opactwa św. Pawła7. W I268 r. majątek przeszedł na własność kościoła św. Sabiny ${ }^{8}$, a następnie przejęła go rodzina Orsinich. W 1295 r. właścicielami majątku stała się rodzina Savellich, która zbudowała zamek otoczony murem z sześcioma lub ośmioma wieżami. Miasto nosiło wówczas nazwę Castrum Leonis (Zamek Lwów) ${ }^{9}$. W XV w. nazwa została zniekształcona na Castel di Leo albo Castel di Leone. Od XviII w. miejsce to nazywa się

4 Por. C.Ch. Canta, Sfondare la notte. Religiosità, modernità e kultura nel pellegrinaggio notturno alla Madonna del Divino Amore, Milano 2004.

5 Fosse Ardeatine to miejsce masowej egzekucji 335 Włochów i Żydów zamordowanych przez Niemców 24 III I944 r. Zbrodni dokonano w odwecie za zamach na kolumnę niemieckiej policji, przeprowadzony w Rzymie przez członków włoskiego ruchu oporu. Masakra w Grotach Ardeatyńskich stała się symbolem niemieckich zbrodni popełnionych we Włoszech w czasie II wojny światowej. Jak ustalili historycy, najmłodszy z zamordowanych miał piętnaście lat, a najstarszy siedemdziesiąt. Por. J. Staron, Fosse Ardeatine e Marzabotto. Storia e memoria di due stragi tedesche, Bologna 2007.

6 N. Tommasini, Il Divino Amore. Storia, tradizione, pietà popolare, Roma 1997, s. 10.

7 Wśród dóbr należących do Opactwa św. Pawła wymienia się także: casale quo vocatur Castellione (inferius at ut Castel di Leva), cum casale iuxta Se quod vocatur Filioli, cum terris, sylvis, pratis, pascus, vel cum omnibus ad Ipsos pertinentibus. G. Silvestrelli, Città, castelli e terre della Regione romana. Ricerche di storia medioevale e moderna sino all'anno I80o, Roma I940, s. 210.

8 Bulla Klemensa IV z 3I III I268 r. zezwalała opatowi św. Pawła na sprzedaż niektórych nieruchomości, wśród nich osady Castellione. Por. G. Silvestrelli, dz. cyt., s. 2 II.

9 G. Tomassetti, La Campagna Romana, antica, medioevale e moderna, Roma 1975, s. 503. 
Castel di Leva. Wraz z upływem czasu budowla ta coraz bardziej traciła na znaczeniu, aż w końcu popadła w ruinę. Niektóre źródła podają, że na tych terenach wystąpiło trzęsienie ziemi. Odnotowano też przypadki malariii ${ }^{10}$.

Tereny wokół zamku nie były zbyt atrakcyjne i zupełnie nie nadawały się do uprawy. Tym prawdopodobnie należy tłumaczyć fakt, że w pobliżu zamku nie powstała żadna większa osada ${ }^{\mathrm{II}}$. Jedynie w okresie zimowym, kiedy ustawały już letnie upały i okoliczne wzgórza pokrywały się zieloną trawą, pojawiali się tu pasterze wraz z owcami ${ }^{2}$. W ciągu lat ukształtował się zwyczaj, zgodnie z którym pasterze gromadzą się na wzgórzu w pobliżu ruin zamkowych, aby oddawać cześć Maryi, głównie odmawiając różaniec $^{13}$. To właśnie wyobrażenie Madonny widniało na murze jednej z baszt zamkowych, która w odróżnieniu od pozostałych, nie uległa zniszczeniu, lecz zachowała się niemal w całości.

Fresk znajdujący się po zewnętrznej stronie muru przedstawiał Matkę Bożą siedzącą na tronie z Dzieciątkiem. Obraz przedstawia Jezusa na prawym ramieniu Maryi, dwa anioły stojące po lewej i po prawej stronie oraz gołębicę, symbol Ducha Świętego, zstępującą na Maryję. Postać z malowidła zamkowego otrzymała tytuł Madonny Bożej Miłości ${ }^{14}$.

Wiosną $1740 \mathrm{r}$. w pobliżu ruin zamkowych, jak wynika z legendy, miało miejsce niecodzienne zdarzenie, które zadecydowało o przyszłości tego miejsca ${ }^{15}$. Otóż pewien człowiek udający się z pieszą pielgrzymką do Rzymu zgubił drogę właśnie w okolicach Castel di Leva ${ }^{16}$. Zobaczywszy w oddali jakieś zabudowania na wzgórzu, udał się w ich kierunku z nadzieją na pomoc w odnalezieniu drogi. Niestety, gdy zbliżył się do ruin zamkowych, został nagle zaatakowany przez stado bezpańskich psów, które z pewnością zagryzłyby nieszczęśnika na śmierć, gdyby - jak opowiadali miejscowi - nie cudowna interwencja Matki Bożej. Przerażony i owładnięty rozpaczą, gdy stracił już wszelką nadzieję na uratowanie, człowiek ów dostrzegł podobiznę

Io Atti della Giunta per l'Inchiesta agraria e sulle condizioni della classe agricola, XI, t. I, I883, capp. v-VI.

I I Por. J. Coste, I casali della Campagna Romana all'inizio del Seicento, „Archivio della Società Romana di Storia Patria" 1969, nr 92, s. 5.

I2 A. Campagna, La Madonna del Divino Amore, Storia e Spiritualità del Santuario, Roma 2019, s. 4.

I3 E.M. Pezzani, La Madonna SS.ma del Divino Amore. Memoriestoriche. Relazioni di grazie. Devotiesercizi, Roma 1908, s. 35; E. Metalli, Usi e costumi della Campagna Romana, Roma 1924, s. 17.

I 4 Dokładne badania fresku przeprowadził w i940 r. prof. Carlo Del Vecchio. Potwierdził on, że obraz został namalowany na przełomie wieków XIII i XIV przez nieznanego artystę należącego najprawdopodobniej do słynnej rzymskiej szkoły Pietro Cavalliniego, tego samego, którego krytyka nowożytna uznała za duchowego mistrza Giotta.

I5 G. Zamboni, Brevi notizie storiche del Santuario della Madonna Santissima del Divino Amore, Roma I873, s. I0-II.

I6 Historia nie odnotowała jego imienia. Jeden z przekazów podaje, że był księdzem. 
Madonny na murze wieży i natychmiast pod wpływem silnego impulsu wewnętrznego zwrócił się do Niej z błagalnym wezwaniem o ratunek. Zaledwie rozbrzmiał w powietrzu jego desperacki okrzyk, szarpiące go psy odstąpiły jak na komendę i rozproszyły się, jakby pod wpływem jakiejś tajemniczej siły. Uratowany ze śmiertelnego niebezpieczeństwa pielgrzym nie miał najmniejszych wątpliwości, że ocalenie - według przekazu - zawdzięcza Maryi, czego nie omieszkał oznajmić ludziom mieszkającym w okolicy i tym, których spotkał później w drodze do Wiecznego Miasta ${ }^{17}$.

Wieść o cudownym wizerunku Madonny szybko rozniosła się po całej okolicy i dotarła aż do samego Rzymu. W efekcie spontanicznie powstał bardzo intensywny ludowy ruch pielgrzymkowy. Do Castel di Leva z dnia na dzień zaczęły przybywać coraz liczniejsze rzesze ludzi. Pielgrzymi wchodzili na wzgórze zamkowe z zapalonymi świecami, z kwiatami, aby modlić się u stóp Matki Bożej Miłości. O szczególne wstawiennictwo zwracały się do Niej zwłaszcza osoby, które znajdowały się w trudnym czy wręcz beznadziejnym położeniu ${ }^{18}$.

Jak wynika ze starych podań, cud z wiosny $\mathrm{I} 740 \mathrm{r}$. był tylko pierwszym $\mathrm{z}$ całej seriii ${ }^{19}$. Aby uporządkować szybko i żywiołowo rozszerzający się kult wizerunku, władze kościelne w osobie wikariusza Rzymu kard. Giovanniego Guadagniego zadecydowały o przeniesieniu fresku z wieży zamkowej w Castel di Leva do niewielkiego kościoła Santa Maria ad Magos znajdującego się w posiadłości ziemskiej Falcognana ${ }^{20}$ w pobliżu tego miejsca ${ }^{21}$.

17 U. Terenzi, La Madonna Santissima del Divino Amore. Cenni storici, Roma I931, s. I5.

I8 F. Valesio, Diario, Milano 1979, s. 382.

I9 Przed kilku laty głośnym echem odbił się cud kobiety z Cassino, która od lat cierpiała na chorobę Parkinsona. Choroba dokonała ogromnego spustoszenia w jej organizmie, tak, że nie mogła już ustać o własnych siłach. Pewnego dnia chora wyraziła życzenie odbycia pielgrzymki do sanktuarium Divino Amore. Rodzina zaniosła ją na noszach przed cudowny obraz Madonny. W czasie Mszy chora zaczęła krzyczeć, że widzi oślepiające światło i w nim Pana Jezusa. Po powrocie do domu dano jej zastrzyk uspakajający i położono do łóżka. Jakież było zdziwienie rodziny, kiedy następnego dnia kobieta obudziła się zupełnie zdrowa; przygotowała śniadanie dla męża i dzieci, posprzątała dom i zdążyła zrobić pranie. Natychmiast wezwano lekarza prowadzącego, który nakazał przeprowadzenie szczegółowych badań. Badania powtórzono wielokrotnie, ale za każdym razem dawały negatywny wynik, tak jakby kobieta nigdy nie była chora na Parkinsona. Cud ten badała nawet specjalna komisja watykańska. Uzdrowiona kobieta poszła podziękować Matce Bożej, ale już nikt nie musiał jej nieść. Uczyniła to o własnych siłach i odbyła pieszą pielgrzymkę. (Na podstawie materiału A. Nicoletti z portalu informacyjnego $\mathrm{TG}_{24}$.info z 15 sierpnia 2015 r.).

20 E. Di Felice, Brevi considerazioni sul distretto della Falcognana tra il XVII e il XVIII secolo, con particolare riferimento alla tenuta di Castel di Leva (Santuario del Divino Amore), [w:] Il Lazio tra antichitá e medioevo. Studi in memoria di Jean Coste, red.Z. Mari, M.T. Petraia, M. Sperandio, Roma 1999, s. 24I-252.

2I Niestety, w tamtych czasach zabrakło fachowej ekspertyzy. Oderwanie fresku od ściany spowodowało jego uszkodzenie, którego nie dało się już naprawić. Późniejsze prace konserwatorskie jeszcze ten stan pogorszyły. 
Pięć lat później cudowny wizerunek Madonny powrócił do Castel di Leva, ale już nie na wieżę, lecz do nowego kościoła wybudowanego na miejscu ruin zamkowych ${ }^{22}$. Na mocy rozporządzenia papieża Benedykta XIV, każdy pielgrzym odwiedzający to miejsce $\mathrm{w}$ dniu przeniesienia obrazu i przez kolejnych siedem dni mógł otrzymać odpust cząstkowy. Kościół został uroczyście konsekrowany 3 I V I750 r. przez biskupa Padwy, kard. Carlo Rezzonico, późniejszego papieża Klemensa XIII.

W I76I r. doszło do kradzieży i wtedy postanowiono przenieść wszystkie wota i klejnoty podarowane sanktuarium w bezpieczniejsze miejsce. Początkowo opieka nad nowym sanktuarium była bardzo problematyczna, biorąc pod uwagę jego położenie w odosobnionym miejscu, które było łatwo dostępne dla złodziei. Skonsultowano dziesiątki zakonów, ale członkowie żadnego nie kwapili się do podjęcia tak trudnego zadania. Sanktuarium powierzono najpierw pustelnikowi ${ }^{23}$, a następnie w I805 r. kapłanom ${ }^{24}$, którzy obsługiwali sanktuarium w okresie Pięćdziesiątnicy, kiedy pielgrzymki były liczniejsze.

W stulecie pierwszego cudu odrestaurowano kościół i stary ołtarz, ozłocono stiuki, zainstalowano dwa nowe ołtarze i postawiono liczne konfesjonały. Przewidując dużo większy napływ pielgrzymów, sanktuarium zostało powiększone o tymczasową drewnianą konstrukcję. Z Rzymu sprowadzono chorągwie, tkaniny, adamaszki, kielichy, monstrancje i inne naczynia kościelne. Korony Maryi i Dzieciątka zostały ozdobione nowymi klejnotami. Naprawiono będącą w bardzo złym stanie Via Ardeatina, która prowadzi do sanktuarium, zbudowano mosty, poszerzono i wyrównano przejścia. Obchody, w których uczestniczył także król Portugalii Michał, rozpoczęły się 7 czerwca I840 r., w niedzielę Zesłania Ducha Świętego. Trwały przez cały tydzień. Wzięło w nich udział dziesięć razy więcej pielgrzymów niż normalnies.

Po obchodach stulecia rozpoczął się powolny okres dekadencji. Wokół sanktuarium, zwłaszcza w dniach poprzedzających Zielone Świątki, pojawiało się mnóstwo straganów z typowymi produktami w tej części Włoch, którymi do dziś są porchetta ${ }^{26}$, pecorino ${ }^{27}$, fava $^{28} \mathrm{i}$ wino. Charakterystycznym

\footnotetext{
22 Kościół wybudował Filippo Raguzzini, architekt z Kampanii.

23 Pierwszym pustelnikiem był Pasquale Francesco.

24 O kontrolę nad sanktuarium Divino Amore i prawo wyznaczania kapłanów do posługi tamże walczyło Konserwatorium św. Katarzyny, a w późniejszych latach Kapituła św. Jana na Lateranie.

25 G. Zamboni, dz. cyt., s. 16.

26 Pieczone prosię.

27 Ser owczy.

28 Bób.
} 
rysem tego miejsca są kobiety, które same określają się jako madonnare. Są to głównie kobiety pochodzące z ludu, przeważnie praczki i straganiarki, które w poniedziałek Zesłania Ducha Świętego obchodzą tam swoje doroczne święto. Setkami gromadzą się one w pobliżu sanktuarium, aby jeść, pić i bawić się, nie zważając na bliskość i świętość miejsca. Odtąd pielgrzymowanie do Divino Amore stało się synonimem wycieczki poza mury miasta i zatraciło swój pierwotny charakter religijny. To pomieszanie sacrum i profanum doprowadziło do stopniowego upadku sanktuarium.

Wraz z upadkiem Państwa Kościelnego w I870 r. i konfiskatą dóbr kościelnych okres opuszczenia i degradacji sanktuarium jeszcze się pogłębił. Nie zahamowała tej tendencji nawet koronacja wizerunku Madonny Bożej Miłości dokonana w 1883 r. przez Kapitułę Rzymską. Kilkadziesiąt lat później sanktuarium Divino Amore znajdowało się w opłakanym stanie. Jeden z redaktorów watykańskiego dziennika „L’Osservatore Romano” tak je opisał:

W kwietniu 1930 r. znalazłem sanktuarium w bardzo smutnym położeniu. W dniach pogodnych wydawało się ono ruiną, wspomnieniem. [...] Było zimne, zadymione, milczące, ciemne: bardziej cmentarz niż sanktuarium. [...] Wszystko znajdowało się w stanie rozkładu [...] sterty śmieci wokół kościoła, a także w pobliżu ołtarza Madonny. [...] W samym kościele brak czystości i porządku, [...] niemily zapach wokół i napisy na ścianach świątyni ${ }^{29}$.

Stan opuszczenia i zaniedbania zachęcał wręcz do aktów wandalizmu i grabieży. W czerwcu 1930 r. podczas włamania dokonanego przez nieznanych sprawców skradziono m.in. srebrne wota i złoty płaszcz okrywający postać Maryi na cudownym wizerunku. Paradoksalnie, ten skandaliczny czyn przyczynił się do odrodzenia sanktuarium. Sprawa kradzieży trafiła do prasy, a wzburzenie okolicznych mieszkańców i wielu czcicieli cudownego wizerunku było tak wielkie, że władze kościelne jeszcze w grudniu tego samego roku, po dwumiesięcznych pracach specjalnej komisji, ustanowiły w sanktuarium rektorat, mianując pierwszego rektora. Został nim młody ks. Umberto Terenzi z diecezji rzymskiej. Miał on niełatwe zadania do wypełnienia: uporządkowanie struktury sanktuarium, zorganizowanie na nowo pobożności maryjnej, wdrożenie nowych form pracy duszpasterskiej, wyeliminowanie licznych nadużyć. Szczególnie to ostatnie zadanie było trudne do zrealizowania, a także - jak się okazało - niebezpieczne. Grupa świeckich, która z sanktuarium czerpała ogromne zyski, niechętnie przyjęła stałą obecność księdza na terenie sanktuarium. Niechęć ta stała się tak 
wielka, że dwukrotnie próbowano pozbawić go życia ${ }^{30}$. Ks. Terenzi nie dał się jednak zastraszyć. Dzięki jego uporowi i niestrudzonej pracy dokonało się szybko prawdziwe odrodzenie sanktuarium. W kwietniu I93 I r. między sanktuarium a Rzymem została uruchomiona regularna usługa transportu samochodowego i stacja kolejowa na linii Rzym - Neapol. Zbudowano dworzec kolejowy i przedszkole. Wkrótce sanktuarium stało się własnością Wikariatu Rzymskiego ${ }^{31} ; 8$ XII 1932 r. powstała tam parafia ${ }^{32}$, a ks. Terenzi został pierwszym proboszczem. W celu pogłębiania kultu maryjnego ks. Terenzi założył żeńskie zgromadzenie zakonne Córek Matki Bożej Miłości (Congregazione delle Figli e della Madonna del Divino Amore), natomiast po wojnie powstało zgromadzenie męskie Synów Matki Bożej Miłości. Aktualnie oba te zgromadzenia obecne są w sanktuarium ${ }^{33}$.

Na szczególną uwagę zasługuje los wizerunku w okresie drugiej wojny światowej. We wrześniu $1943 \mathrm{r}$. w pobliżu sanktuarium omyłkowo wziętym za fortyfikację spadły bomby sił alianckich. Dlatego w wikariacie rzymskim zdecydowano o przeniesieniu cudownego wizerunku Madonny z sanktuarium do centrum Rzymu. W styczniu I944 r. obraz został umieszczony w małym kościele Matki Bożej Miłości, ale ze względu na coraz większe tłumy wiernych, pod koniec maja przeniesiono go do kościoła S. Lorenzo in Lucina ${ }^{34}$, a stamtąd do jeszcze większego kościoła św. Ignacego.

Papież Pius XII wezwał do gorącej modlitwy i złożenia ślubu Maryi, aby Rzym został oszczędzony od walki dwóch armii: niemieckiej i anglo-amerykańskiej. Dnia 4 VI I944 r. lud rzymski wołał o ocalenie miasta i ślubował poprawić własne życie moralne, wznieść nowy kościół ku czci Madonny Bożej Miłości oraz podjąć tam dzieła miłosierdziaas. W opinii

$30 \mathrm{~W}$ ciągu pierwszych dwóch tygodni w sanktuarium w Castel di Leva dwa razy bandyci próbowali pozbawić go życia. Ks. Terenzi postanowił więc zrezygnować z funkcji mu powierzonej. Kiedy jechał do kardynała wikariusza Rzymu, aby zakomunikować swoją decyzję, niedaleko od sanktuarium rozbił się na zakręcie. Ktoś uszkodził jego pojazd. Kapłan cudem ocalał, a samochód nadawał się tylko do kasacji. Jeszcze bardziej przekonany o słuszności swej decyzji wycofania się z powierzonej mu misji, zwierzył się swojemu przyjacielowi, ks. Alojzemu Orione. Ks. Orione, którego Jan Paweł II ogłosił świętym, przekonał zniechęconego ks. Terenziego, że to Maryja cudowanie go ocaliła i ma wracać do sanktuarium. Posłuchał jego rady i powrócił do sanktuarium Matki Bożej Miłości. Wytrwał na posterunku ponad 40 lat, aż do momentu swojej śmierci, 3 I 1974 r. Aktualnie trwa jego proces beatyfikacyjno-kanonizacyjny.

3I Dokonało się to na mocy listu apostolskiego Piusa X Quamdiu per agri romani z dnia 24 V I9I2.

32 Dekret kardynała wikariusza Diecezji rzymskiej, kard. Francesco Marchetti Selvaggianiego Cum Summus Pontifex z I V 1932.

33 Por. P. Pietra, La Madonna del Divino Amore. Cenni storici, Roma 1958, s. 49-52.

34 Obraz przewieziony do miasta ożywił wiarę, pobożność i nadzieje rzymian. Miesięcznik „La Civiltà Cattolica” odnotował, że każdego dnia udzielano w tym miejscu ponad is tys. komunii (rocznik 1944, II, s. 403).

35 Tekst ślubowania rzymian znajduje się w Positio super virtuibus, doc. IV, s. I3. 
wiernych Maryja dokonała cudu - Rzym został bowiem uratowany wraz z jego zabytkami, kościołami i muzeami. Niemcy wycofali się bez walki, a do Rzymu triumfalnie wkroczyły wojska alianckie. II czerwca papież Pius XII przybył do kościoła św. Ignacego, aby się modlić przed obrazem Matki Bożej Miłości i otoczony niezliczonym tłumem wiernych wygłosił swoje podziękowania Maryi. Nadał jej przy tym tytuł Salvatrice dell’Urbe (Wybawicielka Miasta) ${ }^{36}$.

Po zakończeniu wojny wizerunek Madonny wrócił do sanktuarium w Castel di Leva, eskortowany na całej trasie przez olbrzymi tłum wiernych. Dzięki gorliwej pracy ks. Terenziego w szybkim czasie stało się ono ośrodkiem dynamicznie rozwijających się dzieł miłosierdzia, inicjatyw kulturalnych i apostolskich ${ }^{37}$. Powstało tu seminarium Oblatów Bożej Miłości zarządzających sanktuarium i dbających o jego duchowy wymiar, zaś członkinie Zgromadzenia Córek Matki Bożej Miłości zajęły się posługą dzieł charytatywnych, takich jak prowadzenie przedszkola i niesienie pomocy młodocianym w trudnej sytuacji. Inna cenna inicjatywa to obszerny i nowoczesny Dom Opieki dla osób starszych.

W 1947 r. ks. Terenzi na miejscu średniowiecznej cysterny na wodę znajdującej się dawniej w pobliżu zamku zbudował mały kościół z mozaiką Dobrego Pasterza w absydzie i grobem Chrystusa, gdzie Matka Boża Bolesna trzyma w dłoniach martwe ciało Jezusa. Właśnie u Jej stóp spoczywają doczesne szczątki świątobliwego rektora sanktuarium ${ }^{38}$.

W I983 r. została ukończona budowa Domu Pielgrzyma przeznaczonego nie tylko do przyjmowania coraz liczniej przybywających do sanktuarium wiernych, ale też będącego miejscem spotkań, sympozjów, rekolekcji. Została również oddana do użytku Kaplica Spowiedzi, aby wyjść naprzeciw tym, którzy przybywają do sanktuarium przede wszystkim po to, by pojednać się z Bogiem. Największą inicjatywą budowlaną ostatnich lat jest nowe sanktuarium, którego budowę podjęto, by spełnić śluby, które rzymianie złożyli w czasie drugiej wojny światowej. Budowa rozpoczęła się w $1992 \mathrm{r}$. i zakończono ją przed Wielkim Jubileuszem Roku 2000. Nowy kościół może pomieścić 1,5 tys. pielgrzymów i został wzniesiony według nowoczesnego

36 S. Ficacci, M.T. Natale, Ig luglio 1943-4 giugno 1944: Roma verso la liberta, Roma 2014, s. 2 I.

37 W 1946 r. rozpoczęto publikację pisma „Parrocchia”, zaś w I954 r. pisma „La Madonna”. Oprócz tego wznowiono wydawanie ukazującego się jeszcze przed wojną biuletynu „La Madonna del Divino Amore".

38 Interesującą biografię ks. Terenziego napisał jeden z jego duchowych synów. Por. G. Meaolo, Ave Maria... e coraggio! Don Umberto Terenzi, prete romano, Roma 1992; zob. także: Celebrando so anni di sacerdozio di don Umberto Terenzi: l'opera da lui fondata e diretta offre ricordi e testimonianza a quanti la conoscono e lostimano per l'apostolato da lui svolto all'ombra della Madonna del Divino Amore, Roma 1973. 
projektu architektonicznego ${ }^{39}$; znajduje się u stóp wzgórza, poza murami otaczającymi kompleks budynków należących do starego sanktuarium.

O wielkiej roli, jaką sanktuarium Madonny del Divino Amore odgrywa w całym regionie Lacjum, może świadczyć fakt, że jest ono miejscem, do którego trzykrotnie pielgrzymował Jan Paweł II. Przypomina o tym mozaika z wizerunkiem papieża, która wita pielgrzymów u wejścia do nowej części kościoła. Polski papież odwiedził sanktuarium w latach $1979,1987^{4 \circ}$ i 1999, kiedy konsekrował nowe sanktuarium. Modlili się tam również jego następcy Benedykt XVI ${ }^{41}$ i Franciszek ${ }^{42}$.

Przejawem kultu Matki Bożej z Divino Amore są także liczne kapliczki rozsiane po całym Rzymie. Można je zobaczyć na ścianach budynków i urzędów, z charakterystycznym napisem: per Grazia ricevuta - „za otrzymaną łaskę". Wiele z tych byłych wotów było umieszczonych na murach Aureliana w pobliżu polikliniki Bambino Gesù. W latach 80 . Xxw. rozebrano je i przeniesiono w inne miejsca. Część z nich zamontowano na zewnętrznych ścianach sanktuarium.

Odwiedzając Divino Amore, nie sposób pominąć sal, w których ściany obwieszone są wotami, będącymi wyrazami wdzięczności za uratowane życie i otrzymane łaski. Wrażenie na przybywających robią szczególnie zdjęcia ludzi na tle wraków samochodów i samolotów. Warto zatrzymać się przy słuchawkach radiotelegrafisty Giuseppe Biagiego, uczestnika nieszczęsnej wyprawy na biegun północny ${ }^{43}$.

W sanktuarium znajduje się także wiele innych pamiątek: tabliczki, obrazy, zdjęcia, śliniaczki, wydruki z badania USG, czapeczki, ubranka

39 Projekt nowego sanktuarium sporządził franciszkanin, o. Costantino Ruggeri (1925-2007), słynny we Włoszech malarz, rzeźbiarz i budowniczy kościołów.

40 Jan Paweł II otworzył tam Jubileuszowy Rok Maryjny.

4I Niemiecki papież modlił się tam I V 2006 r.

42 Aktualny biskup Rzymu odwiedził sanktuarium i V $2018 \mathrm{r}$.

43 Dnia 24 V 1928 r. włoski sterowiec Italia pod dowództwem gen. Umberto Nobilego wylądował na biegunie północnym, zatykając tam flagę włoską i złoty krzyż podarowany przez papieża Piusa XI. Dzień później, podczas powrotu, przeciążona oblodzeniem maszyna opadła na lód i zderzyła się z krą lodową. Zginęła część załogi, a na lodzie pozostało dziewięciu ludzi. Rozbitkowie mieli do dyspozycji namiot (po zabarwieniu go stał się znany jako Czerwony Namiot), radio i pewien zapas żywności. Przez wiele dni radio mimo nieustannych prób milczało jak zaklęte. Wtedy to radiotelegrafista przyrzekł Madonnie Bożej Miłości, że jeśli tylko wyjdą z życiem z tej opresji, to ofiaruje jej swój zestaw słuchawkowy. Po osiemnastu dniach nagle radio zaczęło działać i nawiązano łączność ze światem. Rozbitkowie zostali odnalezieni przez lotników szwedzkich, którzy zrzucali im zaopatrzenie na krę. Szwedzi zabrali na pokład rannego gen. Nobilego. Ostatnich pięciu rozbitków, w tym radiotelegrafistę Biagiego uratował radziecki lodołamacz Krasin, I7 VII I 928 r., czyli po 48 dniach izolacji i cierpienia. Łącznie w katastrofie zginęło ośmiu ludzi, zaś w akcji ratunkowej śmierć poniosło dziewięć osób. Uratowano tylko ośmiu uczestników wyprawy. Katastrofę tę opisał m.in. Umberto Nobile w książce Czerwony namiot, (Warszawa 1976) oraz drugi uratowany uczestnik ekspedycji, Czech, František Běhounek, we wspomnieniach Rozbitkowie na morzu polarnym (Katowice 1974). 
chrzcielne. Są także wota włoskich sportowców wszystkich dyscyplin, m.in. rower F. Mosera, narty A. Tomby oraz sportowców zagranicznych, od E. Merckxa, mistrzów motoryzacji i kolarstwa, aż po piłkarzy, w tym wielu zawodników z rzymskich klubów Lazio i Roma. W krypcie sanktuarium znajduje się grób błogosławionych Marii i Alojzego Beltrame Quattrocchi, pierwszej pary małżeńskiej wyniesionej przez Jana Pawła II do chwały oltarzy ${ }^{44}$.

A.B. Quattrocchi urodził się w Katanii na Sycylii I2 I I880 r. Kiedy miał jedenaście lat, rodzina przeniosła się do Rzymu, gdzie Alojzy podjąt studia prawnicze na uniwersytecie La Sapienza. W I 905 r. ożenił się z Marią Corsini. Ślub odbył się w bazylice Matki Bożej Większej. Alojzy był cenionym adwokatem i obejmował coraz to wyższe, prestiżowe stanowiska w instytucjach państwowych. Pracę w strukturach państwa traktował jako pokorną służbę. W I939 r. odrzucił propozycję objęcia urzędu adwokata generalnego, a w 1948 r. odmówił startu w wyborach do senatu. Jego nieskazitelne życie moralne i głęboka, publicznie wyrażana wiara chrześcijańska, skłoniły wielu jego kolegów do nawrócenia i powrotu do życia sakramentalnego. Zaraz po wojnie wraz z żoną opiekował się dziećmi i młodzieżą z ubogich dzielnic Rzymu, angażując się w tworzenie i organizowanie włoskiego harcerstwa, widząc w nim szanse do integralnego wychowania młodego pokolenia w duchu wiary i wartości chrześcijańskich. Dla pogłębienia swojej wiedzy religijnej uczęszczał na wieczorne kursy teologiczne dla świeckich organizowane przez jezuitów na Uniwersytecie Gregoriańskim i uczestniczył w spotkaniach poświęconych kulturze religijnej. Zmarł w Rzymie w i95 r r.

Maria Ludwika Corsini urodziła się we Florencji 24 VI I884 r. Rodzice jej zdecydowali się osiąść w Rzymie. W szkole miała szczęście spotkać nauczycieli o wybitnej kulturze, którym zawdzięczała wszechstronne wykształcenie humanistyczne. Wyróżniała się nieprzeciętną inteligencją. Już w szkole średniej rozwinęła zdolności pisarskie, które wykorzystała później w publikacjach, poświęconych głównie problematyce rodziny chrześcijańskiej i wychowaniu dzieci. To dzięki niej mąż Alojzy stał się gorliwym katolikiem. Wieczorem cała rodzina kończyła dzień wspólną modlitwą różańcową. Maria była też wolontariuszką Czerwonego Krzyża. W czasie drugiej wojny światowej organizowała pomoc dla uchodźców. Razem z mężem działała w Akcji Katolickiej i innych stowarzyszeniach, oddawała się także pracy charytatywnej, zwłaszcza opiece nad chorymi. Oboje z mężem zostali tercjarzami franciszkańskimi. Zmarła

44 Beatyfikacja miała miejsce 2r X 200I r. w Bazylice św. Piotra na Watykanie. W uroczystości uczestniczyło troje dzieci błogosławionych: 95-letni Filip (ksiądz Tarsycjusz), 92-letni Cezar (o. Paolino, trapista), 87-letnia Enrichetta. Brakowało Stefanii (siostry Cecylii, benedyktynki) zmarłej w 1993 r. 
w 1965 r. O głębokim życiu duchowym rodziny Quattrocchich świadczy fakt, że troje ich dzieci wybrało drogę powołania kapłańskiego i zakonnego, a najmłodsza córka - Enrichetta - wybrała życie samotnej konsekrowanej osoby świeckiej. W $2018 \mathrm{r}$. rozpoczą się jej proces beatyfikacyjny.

To właśnie w tym sanktuarium, I3 VIII 1940 r. obecnie błogosławiona, Maria Beltrame Quatrrocchi powierzyła swoje dzieci opiece Matki Bożej Miłości. W czasie wojny, najstarszy syn błogosławionych małżonków, ks. Filip, uciekł I3 VIII I 942 r. ze storpedowanego okrętu. Drugi syn, Cezary, kapelan wojskowy, I3 VIII 1943 r. podczas zbierania ciała poległego żołnierza, uszedł z życiem, uciekając przed strzałami snajpera. Tego samego dnia ich córka Stefania, która w zakonie przyjęła imię siostry Cecylii, wyszła z klasztoru w Mediolanie tuż przed tym, jak został zbombardowany.

W sanktuarium Divino Amore jest jeszcze jedno ciekawe miejsce zwane sanktuarium Cyganów. Powstało w 2004 r. i jest ono poświęcone błogosławionemu Zefirynowi Giménezowi Malli ${ }^{45}$, cygańskiemu katolikowi zastrzelonemu w 1936 r. podczas hiszpańskiej wojny domowej ${ }^{46}$. Oprócz elementów dekoracyjnych znajduje się tam tablica upamiętniająca 500 tys. Cyganów zamordowanych przez hitlerowskie Niemcy w czasie drugiej wojny światowej. Każdego roku, 4 maja, pielgrzymują do tego miejsca Cyganie żyjący w różnych częściach świata, nie tylko katolicy.

Mieszkańcy Rzymu nie zapomnieli o cudownym uratowaniu ich miasta w czasie wojny i o ślubach wtedy złożonych. Nadal uciekają się do swojej Patronki w sprawach trudnych czy wręcz beznadziejnych. Przed jej obrazem modlą się całe rodziny, zakochane pary i młode małżeństwa, zwłaszcza te, które

45 Index ac status causa rum beatificationis et canonizationis quae a Postulatione Generali OFM pertractantur. Roma 2009, s. 70.

46 O wczesnych latach życia Zefiryna Giméneza Malli (186I-1936) wiadomo niewiele, poza tym, że jak większość ówczesnych Romów często zmieniał miejsce pobytu. Chrzest przyjął już jako człowiek dorosły. W wieku lat 5 I ożenił się z Teresą Castro. Małżeństwo to było bezdzietne, ale adoptowało bratanicę Teresy, Pepitę. Giménez Malla, dzięki handlowi końmi i mułami, stał się na tyle zamożny, że kupił dom w Barbastro. W 1922 r. zmarła jego żona. Zefiryn aktywnie uczestniczył w życiu religijnym i został nawet katechetą. Był również dyrygentem chóru i kierownikiem kółka różańcowego, należał także do Trzeciego Zakonu Franciszkańskiego. Miał duży autorytet w miejscu zamieszkania. Często zwracano się do niego z prośbą o arbitraż przy rozstrzyganiu sporów. W 1936 r. w czasie wojny domowej w Hiszpanii stanął w obronie księdza wleczonego po ulicy za nogi. W trakcie zatrzymania u Zefiryna znaleziono różaniec. W celi więziennej nie skorzystał z propozycji uwolnienia w zamian za zaprzestanie modlitwy różańcowej. 8 VIII 1936 r. został rozstrzelany. Przed śmiercią wypowiedział słowa: „Niech żyje Chrystus Król”. Beatyfikował go Jana Paweł II, 4 V 1997 r., jako męczennika, gdyż jego śmierć miała wyraźny związek z wyznawaną przez niego wiarą. Uroczystość beatyfikacji odbyła się w Rzymie i uczestniczyło w niej ok. 40 tys. wiernych, w tym wielu Romów z różnych stron świata. Zefiryn Giménez Malla jest pierwszym przedstawicielem narodowości romskiej, który został przez Kościół katolicki ogłoszony błogosławionym. Jest też patronem wszystkich Romów. Kompletną i interesującą biografię bł. Zefiryna Giméneza Malli napisał były duszpasterz Romów polskich, ks. Edward Wesołek. Zob. E. Wesołek, Viva Cristo Rey!, Warszawa 2008. 
proszą o dar potomstwa. Sanktuarium nadal obsługują księża i zakonnice ze zgromadzeń założonych przez ks. Terenziego. Gałąź żeńska zgromadzenia ma więcej powołań, głównie z krajów Ameryki Łacińskiej. I choć w dzisiejszych czasach liczba pątników znacznie się zmniejszyła, to jednak - jak wierzą pielgrzymi - Maryja nadal spogląda troskliwie na swoich czcicieli gotowa jak zawsze pocieszyć, przytulić do serca i wypraszać u Syna potrzebne łaski ${ }^{47}$.

\section{Komentarz antropologa do pielgrzymich i kościelnych opowieści o sanktuarium ${ }^{48}$}

Divino Amore to najważniejsze sanktuarium Prowincji Rzymskiej. W jego losach, a także we współczesnej religijnej egzystencji antropolog odnaleźć może znane mu z historii miejsc świętych toposy; pojawiają się też nowe motywy utrwalone przez lata w kościelnych i pielgrzymich opowieściach. Tekst ks. Władysława Zarębczana jest dla antropologa kłopotliwy, bowiem wiele ważnych kwestii z obszaru antropologii religii pozostaje w nim bez odpowiedzi, prowokując do dyskusji, wyjaśnień i uzupełnień.

Cud początkowy. Jak każde tego typu zdarzenie, odmienia i nadaje sens religijny wybranemu miejscu. Przestrzeń w ludzkim doświadczeniu nigdy nie jest jednorodna, zawsze podlega wartościowaniu (w kulturze religijnej - sfery sacrum i profanum). Zdarzenie początkujące egzystencję sanktuarium ma zawsze charakter hierofaniczny ${ }^{49}$. W tym przypadku $\mathrm{w}$ przestrzeni zapomnianej, amorficznej ( $\mathrm{w}$ ruinach nieodwiedzanego zamku) manifestacja sacrum (interwencja Maryi) ustanawia i zmienia charakter miejsca, staje się ono znaczące religijnie. Opowieść o zabłąkanym wędrowcu jest znanym toposem w repertuarze religijnych opowieści etiologicznych. Napadnięty prosi on o pomoc Maryję, zwracając się w stronę wizerunku - fresku zamieszczonego na jedynej ocalałej baszcie zamkowych ruin. Maryja reaguje natychmiast, ratując wędrowca przed śmiercią. Topos natychmiastowej interwencji Najświętszej Maryi Panny początkujący konsekrację niezwykłego miejsca jest także obecny w etiologicznych opowieściach o polskich sanktuariach (m.in. Ludźmierz, Kalwaria Pacławska, Licheń). Uratowany pielgrzym w dalszej drodze do Rzymu opowiadał innym o cudownym zdarzeniu, dając świadectwo niezwykłej interwencji Maryi i sławiąc Jej wizerunek. Z prac Czesława Robotyckiego i Anny

\footnotetext{
47 Pisze o tym jezuita o. T. Repetto, Il fenomeno mariano nei nuovimedia. Il culto di Maria nell'epoca di internet e del cellulare, Roma 2007.

48 Część artykułu napisana przez Ewę Nowina-Sroczyńską - przyp. red.

49 M. Eliade, Traktat o historii religii, przeł. J. Wierusz-Kowalski, Warszawa 2009, s. 38I-400.
} 
Niedźwiedź wiadomo, że aby zdarzenie i opowieść o nim zagościły w świadomości zbiorowej, muszą być poddane dwóm procesom: powtarzalności (transmisji kulturowej) i aktualizacji ${ }^{{ }^{\circ}}$. Z nimi mamy do czynienia w historii Divino Amore. Przekaz uratowanego, powtarzany i aktualizowany, zapoczątkował intensywny ludowy ruch pielgrzymkowy. Cud początkowy konsekrujący przestrzeń ruin zamkowych zdarzył się w $1740 \mathrm{r}$. Niestety, nie można określić statusu i roli obrazu w wiekach wcześniejszych. Wizerunek Madonny - dowiadujemy się z opowieści - czcili pasterze, którzy w sezonowym wypasie owiec często odmawiali różaniec. Pojawiają się pytania: Czy umieszczony na zewnętrznych murach baszty zamkowej fresk miał charakter obronny? Czy już wówczas, w wiekach XIII i XIV, miał charakter palladialny? Jaki był powód jego powstania? Antropologa kusi zebranie wiadomości o trwaniu wizerunku pomimo dokonanych zniszczeń (motyw znany z wielu legend sanktuaryjnych).

Wizerunek. Fresk znajdujący się po zewnętrznej stronie muru przedstawiał Maryję siedzącą na tronie z Dzieciątkiem. Obraz namalowany przez nieznanego artystę ze znanej szkoły rzymskiej Cavalliniego (przełom wieków XIII i XIV) wkrótce otrzymał tytuł Madonny Bożej Miłości. Dlaczego? Kto nadał taki tytuł? Czy miało to związek z otrzymywanymi już wówczas (a nieznanymi) łaskami? Niejasny jest też status obrazu. O jego „hybrydyczności" świadczą fakty: wiele działań religijnych wiązano ze świętem Zesłania Ducha Świętego (Zielonymi Świątkami). Czyżby cud początkowy, ten z 1740 r., wydarzył się właśnie w czasie szczególnej opieki Ducha Świętego? Wiadomo, że temporalne zależności są niezwykle ważne w procesie konstrukcji miejsca świętego.

Wędrówki wizerunków. Opowieści o wędrówce obrazów (i postaci w nich obecnych) pojawiają się w katolicyzmie i prawosławiu, a religijny i symboliczny wyraz nawet najstarszych legend jest wspólny i staje się manifestacją sakralnych mocy, jakie przydają im wierni. Obrazy wędrowały, zmieniały miejsca, miały liczne hierofaniczne przygody. Przybywały one z miejsc oddalonych - to częsty motyw etiologicznych opowieści. Stanowi on echo właściwej dla światopoglądu ludowego kategorii „swojego” i „obcego”; to, co jest tajemnicze, niezwykłe i obce, uchodzi za pośredniczące między światami boskim i ludzkim ${ }^{\text {s. }}$. Obrazy dokonywały wyboru miejsc, w których przedstawione osoby miały być przedmiotem kultu. To wielki topos folkloru religijnego - motyw węzłowy ${ }^{\text {`2 }}$. Wizerunek, wybierając przestrzeń, dokonuje

\footnotetext{
50 Por. Cz. Robotycki, Etnografia wobeckultury wspótczesnej, Kraków 1992; A. Niedźwiedź, Obraz i postać. Znaczenia wizerunku Matki Boskiej Częstochowskiej, Kraków 2005.

sI Tamże, s. so.

52 Tamże, s. 90-91.
} 
jej sakralizacji (przykłady: Jasna Góra, Miedniewice, Kalwaria Zebrzydowska, Piekary Śląskie, Gwadelupa). Sanktuarium Divino Amore potwierdza uniwersalność motywu wędrówki wizerunku. Zdjęty z murów zamkowych i uszkodzony, został przeniesiony do niewielkiego kościoła położonego blisko zamkowych ruin. Po pięciu latach powrócił na pierwotne miejsce do nowo zbudowanej dla niego świątyni. Dzień przeniesienia uczyniono dniem pielgrzymki i odpustu. Konsekracja miejsca niewiele pomogła; zbytnie oddalenie od głównych dróg powodowało liczne dewastacje. Odnowienie znaczenia sanktuarium nastąpiło w stulecie pierwszego zdarzenia mirakularnego. Wraz z upadkiem Państwa Kościelnego nastąpiła powolna utrata znaczenia sanktuarium. W trakcie drugiej wojny światowej wizerunek Maryi ponownie został przeniesiony - do Rzymu, kolejno do trzech kościołów. Po zakończeniu działań wojennych powrócił do Castel di Leva, odprowadzony przez rzesze pielgrzymów, a to z powodu kolejnego spektakularnego zdarzenia cudownego, które uczyniło wizerunek obrazem o charakterze palladialnym.

Status palladialny wizerunku. Ks. W.Zarębczan przypomniał, że papież Pius XII wezwał wiernych do modlitwy i złożenia ślubów Maryi, aby Rzym oszczędzono podczas działań wojennych. 4 VI 1944 r. lud prosił o ocalenie miasta. Rzym został uratowany przed zniszczeniem. Tłum wiernych złożył podziękowanie i nadał Maryi przedstawionej na obrazie tytuł Wybawicielki Miasta. W ten sposób wierni nadali wizerunkowi status palladialny. Zapis pierwotnego wzorca tematu cudownej obrony świątyni (twierdzy, miasta) odnajdujemy już u Herodota ${ }^{53}$ w opisie obrony Delf w 480 r. p.n.e. Opowieść o cudownej obronie wiązano z wieloma zdarzeniami dziejowymi. W Bizancjum motyw ten pojawił się wiele razy. Poszczególne oblężenia i walki toczone w ciągu wieków opisywano w kategoriach mirakularnych. Najważniejszą dla chrześcijaństwa, paradygmatyczną stała się obrona Konstantynopola w $626 \mathrm{r}$. Z tematem cudownej obrony miasta została zespolona opowieść o świętym wizerunku Bogurodzicy, której oddaje się w opiekę miasto oblężone. Procesje z obrazem Matki Bożej Blacherneńskiej po murach miasta, modlitwy i msze spowodowały - jak powszechnie mniemano - cudowną interwencję Maryi ${ }^{54}$. Ten temat wzorcowy, wypracowany „na bazie kultury antycznej, ale odziany w szatę chrześcijańską"ss, odnaleźć można w Europie: Nowogród, Bełz, Lepanto, Chocim, Jasna Góra... Wizerunki chroniące miasta, twierdze i świątynie w zasadzie nie były przenoszone. W Divino Amore jest zgoła inaczej. Dlaczego obraz nie pozostał w miejscu, które ocalił, czyli

53 Herodot, Dzieje, przeł. S. Hammer, Warszawa 2015.

54 Tamże, s. 127-134.

55 Tamże, s. 130. 
w Rzymie? Czy zdarzył się tak częsty w innych historiach sanktuaryjnych cud wyboru miejsca przez wizerunek? Czy też taka była decyzja władz kościelnych? To pytania istotne z punktu widzenia badań antropologicznych. Po zakończeniu wojny obraz powrócił do Castel di Leva. Odtąd obserwowany jest niezwykle dynamiczny rozwój sanktuarium. Powstaje seminarium Oblatów Bożej Miłości, to oni mają zarządzać sanktuarium.

Mąż opatrznościowy. Lektura prac omawiających liczne sanktuaria przekonuje, że ich stróżami stają się przede wszystkim zakony. Los sanktuarium zależy niekiedy od działalności jednostki - męża opatrznościowego dbającego o jego rozwój. W przypadku Divino Amore był nim ks. Terenzi, który w okresie między wojnami powoli budował legendę i instytucjonalny wymiar sanktuarium. O tym, jak wielka może być rola męża opatrznościowego sanktuarium, w Polsce wiadomo choćby z historii Lichenia.

Groby. Sanktuarium Divino Amore staje się powoli nekropolią, co bez wątpienia nadaje mu wymiar instytucji społecznej, która buduje wzory tożsamości. W krypcie znajduje się bowiem grób rodziny Quattrocchich - pierwszej pary małżeńskiej wyniesionej przez Jana Pawła II na ołtarze.

Wątek cygański. Jest on dla antropologa niezwykle ważny. Sanktuarium Cyganów w obrębie całego Divino Amore poświęcone jest błogosławionemu Zefirynowi Malli, katolikowi, który zginął podczas hiszpańskiej wojny domowej. Każdego roku 4 maja sanktuarium podejmuje Cyganów żyjących w różnych częściach świata, będących wyznawcami różnych religii. Ekumeniczny rys zaświadcza o nowym podejściu do miejsc świętych, o ich otwartości na religijną i etniczną różnorodność. Bez wątpienia medialny charakter niektórych współczesnych zdarzeń mirakularnych świadczy o potrzebie aktualizacji treści religijnych i zmian znaczeń pewnych faktów kulturowych ze względu na charakter kontekstów kulturowych, społecznych, politycznych i religijnych.

Konkluzje. Antropologiczny komentarz do kościelnych i pielgrzymich opowieści o Divino Amore jest przyczynkiem do badań etnograficznych nad kategoriami przestrzeni, czasu, wierzeń, zachowań w miejscach sakralnych, w pobożności ludowej, potocznej. Z sanktuarium Divino Amore wiążą się różnorodne wątki - archetypiczne motywy, uniwersalne toposy i nowe formy działań w obrębie miejsca świętego. Toposy „długiego trwania” - tak ważne dla morfologii kulturowej sanktuariów - nie mogą być jednak poddane starannej interpretacji ze względu na brak dostępu do źródeł zastanych i tych najistotniejszych dla antropologa, czyli źródeł wywołanych. Aby antropolog mógł odpowiedzieć na postawione pytania, powinien:

- poznać włoskie źródła archiwalne dotyczące zmiennej historii sanktuarium, a przede wszystkim zapisy legend o zdarzeniach mirakularnych, 
- poszerzyć wiedzę o zdarzeniach, które uczyniły obraz wizerunkiem palladialnym (ten moment wydaje się przełomowy dla dzisiejszej egzystencji sanktuarium),

- dokonać przeglądu i analizy tekstów przewodników kościelnych i świeckich,

- poznać lektury etnograficzne, antropologiczne, religioznawcze i socjologiczne włoskich autorów, których przedmiotem było Divino Amore,

- wreszcie - co może jest postulatem najistotniejszym - podjąć badania terenowe we współczesnym sanktuarium i jego okolicach, trzech rzymskich kościołach, gdzie wizerunek Maryi „przebywał” w czasie drugiej wojny światowej: obserwacje i wywiady, a także dokumentacja ikonografii.

\section{Bibliografia}

\section{Źródła archiwalne}

Archivio di Stato di Roma (ASR) Archivio della Confraternita di Santa Caterina della Rosa o dei Funari

Presidenza Generale del Censo, Catasto Gregoriano, Agro Romano, n. 5: Serie III, b. 47, fasc. I 4; Serie IV, b. 64, fascc. 25-28; Serie viII, b. 409.

Presidenza Generale del Censo, Catasto Gregoriano, Agro Romano, n. 5.

Archivio Segreto Vaticano

Misc. IV, t. 74, cc. 449-506 (Bolle e reditti diversi per le strade di Roma e fuori, I60I-I6II). Atti della Segreteria del Vicariato, Plico n. 226, fasc. I.

Registri parrocchiali, S. Giovanni in Laterano (Campagna). S. Maria ad Magos in Falcognana. Stati delle Anime, 1676.

Registri parrocchiali, Madonna del Divino Amore. Statidelle Anime, I77 I e 1803.

Biblioteca Apostolica Vaticana (BAV)

Diario Ordinario, t. I17, n. 4329, 24 aprile 1745; Diario Ordinario, t. 142, n. 5130 ,

6 giugno 1750; Positio super virtuibus, doc. IV.

\section{Źródła drukowane}

Herodot, Dzieje, przeł. S. Hammer, Warszawa 2015.

Valesio F., Diario, Milano 1979.

\section{Opracowania}

Atti della Giunta per l'Inchiesta agraria e sulle condizioni della classe agricola, Roma I883.

Běhounek F., Rozbitkowie na morzu polarnym, przeł. J. Bułakowska, Katowice 1974.

Campagna A., La Madonna del Divino Amore, Storia e Spiritualità del Santuario, Roma 2019.

Canta Ch.C., Sfondare la notte. Religiosità, modernità e cultura nel pellegrinaggio notturno alla Madonna del Divino Amore, Milano 2004.

Celebrando so anni di sacerdozio di don Umberto Terenzi: l'opera da lui fondata e diretta offre ricordi e testimonianza a quanti la conoscono e lostimano per l'apostolato da lui svolto all'ombra della Madonna del Divino Amore, Roma 1973.

Coste J., I casali della Campagna Romana all'inizio del Seicento, „Archivio della Società Romana di Storia Patria" 1969, nr 92.

Di Felice E., Brevi considerazioni sul distretto della Falcognana tra il XVII e il XVIII secolo, con particolare riferimento alla tenuta di Castel di Leva (Santuario del Divino Amore), 
[w:] Il Lazio tra antichità e medioevo. Studi in memoria di Jean Coste, red. Z. Mari,

M.T. Petraia, M. Sperandio M., Roma 1999.

Eliade M., Traktat o historii religii, przeł. J. Wierusz-Kowalski, Warszawa 2009.

Ficacci S., Natale M.T., Ig luglio 1943 - 4 giugno 1944: Roma verso la liberta, Roma 2014. Metalli E., Usi e costumi Della Campagna Romana, Roma 1924.

Niedźwiedź A., Obraz i postać. Znaczenia wizerunku Matki Boskiej Częstochowskiej, Kraków 2005. Nobile U., Czerwony namiot, przeł. A. Czerniak, Warszawa 1976.

Pezzani E.M., La Madonna SS.ma del Divino Amore. Memorie storiche. Relazioni di grazie. Devoti esercizi, Roma 1908.

Pietra P., La Madonna del Divino Amore. Cenni storici, Roma 1958.

Repetto T., Il fenomeno mariano nei nuovi media. Il culto di Maria nell'epoca di internet e del cellulare, Roma 2007.

Robotycki Cz., Etnografia wobec kultury wspótczesnej, Kraków 1992.

Silvestrelli G., Città, castelli e terre della Regione romana. Ricerche di storia medioevale e moderna sino all'anno I80o, Roma 1940.

Staron J., Fosse Ardeatine e Marzabotto. Storia e memoria di due stragi tedesche, Bologna 2007.

Terenzi U., La Madonna Santissima del Divino Amore. Cenni storici, Roma 1931.

Tommasini N., Il Divino Amore. Storia, tradizione, pietà popolare, Roma 1997.

Tomassetti G., La Campagna Romana, antica, medioevale e moderna, Roma 1975.

Wesołek E., Viva Cristo Rey!, Warszawa 2008.

Zamboni G., Brevi notizie storiche del Santuario di Maria santissima del Divino Amore, Roma 1873.

Streszczenie: Artykuł stanowi kontynuację rekonesansu po małych, peryferyjnych, zapomnianych sanktuariach europejskich. Przedmiotem prezentacji jest sanktuarium Divino Amore we włoskim Castel di Leva położonym na obrzeżach Rzymu. Autorzy przedstawiają jego legendę etiologiczną, źródło ludowego ruchu pielgrzymkowego, złożone dzieje oraz współczesną egzystencję tego miejsca, łącząc w swojej narracji perspektywę historyka, etnografa, teologa i wnikliwego obserwatora aktów religijności. W kościelnych i pielgrzymich opowieściach o sanktuarium autorzy w krótkim antropologicznym komentarzu rozpoznają zarówno toposy dobrze znane z historii miejsc świętych, jak i elementy nietypowe.

Słowa klucze: sanktuarium, legenda etiologiczna, pielgrzymka, peryferia

Summary: The article contributes to the review of small, peripheral, forgotten European sanctuaries. The subject of the presentation is the Sanctuary of Divino Amore in the Italian Castel di Leva located on the outskirts of Rome. Authors present its etiological legend, the source of the folk pilgrimage movement, the complex history and contemporary existence of this place, combining in their narrative the perspectives of a historian, ethnographer, theologian and a keen observer of acts of religiousness. In many church and pilgrim stories about the sanctuary the authors recognize in anthropological commentary topoi well known from the history of holy places, as well as new ones.

Keywords: sanctuary, etiological legend, pilgrimage, periphery 